\title{
Carbon stable isotope-climate association in tree rings of Pinus pinaster and Pinus sylvestris in Mediterranean environments
}

\author{
Asociación entre el clima y los isótopos estables de carbono en los anillos de crecimiento \\ de Pinus pinaster y Pinus sylvestris en ambientes Mediterráneos
}

\author{
Stella M Bogino ${ }^{\mathrm{a}, \mathrm{b} *}$ and Felipe Bravo ${ }^{\mathrm{a}}$ \\ *Corresponding author: ${ }^{a}$ Universidad de Valladolid-INIA, Instituto Universitario de Investigación, Gestión Forestal Sostenible, \\ Avenida de Madrid 44, E-34004 Palencia, España, phone: +54 2657 434545, sbogino@fices.unsl.edu.ar

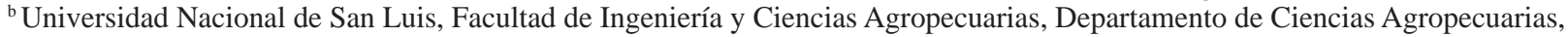 \\ Avenida 25 de Mayo 384, D5730EKQ Villa Mercedes, San Luis, Argentina.
}

\section{SUMMARY}

Carbon isotope ratios, recorded as ${ }^{13} \mathrm{C} /{ }^{12} \mathrm{C}$ variations in tree rings of woody species, are the result of physiological changes related to environmental conditions. The objective of this work was to analyze the association among carbon thirteen variability $\left(\delta^{13} \mathrm{C}\right)$, climate variables and tree-ring growth of Pinus pinaster and Pinus sylvestris in central Spain. Pulverized woody material from the period 1975-1999 from four trees for each pine species was analyzed. To detect common patterns in $\delta^{13} \mathrm{C}$ within each species and between $\delta^{13} \mathrm{C}$ and growth indices, a principal component analysis (PCA) was performed. $\delta^{13} \mathrm{C}$ of trees and the residual tree-ring chronologies were used at the PCA. Multilevel mixed linear models were applied between intrinsic water use efficiency (iWUE) and climate variables. Our results show an inverse significant correlation between $\delta^{13} \mathrm{C}$ and tree-ring growth of both species. Winter and spring air moisture was negatively correlated with iWUE of Pinus pinaster. July maximum temperature was positively correlated with iWUE of Pinus sylvestris. As $\delta^{13} \mathrm{C}$ is significantly related to climate and growth and it may be recommended as a valuable tool for tree growth dynamic analysis to withstand increasingly stressful climate conditions.

Key words: intrinsic water-use efficiency, Mediterranean pines, carbon-isotope, tree ring.

\section{RESUMEN}

La relación entre los isótopos de carbono, almacenada como la variación de ${ }^{13} \mathrm{C} /{ }^{12} \mathrm{C}$ en los anillos de crecimiento de las especies leñosas, es el resultado de cambios fisiológicos relacionados con las condiciones ambientales. El objetivo de este trabajo fue analizar la asociación entre la variabilidad del isótopo de carbono trece $\left(\delta^{13} \mathrm{C}\right)$, las variables climáticas y el ancho de los anillos de crecimiento de Pinus pinaster y Pinus sylvestris que crecen en el centro de España. Se analizó polvo de madera obtenido a partir de los anillos de crecimiento del período 1975-1999 de cuatro árboles de cada especie. Para determinar patrones de variabilidad comunes de $\delta^{13} \mathrm{C}$ y la asociación entre $\delta^{13} \mathrm{C}$ con el crecimiento se aplicó un análisis de componentes principales $(\mathrm{ACP})$ entre la $\delta^{13} \mathrm{C}$ de todos los árboles y las cronologías residuales para cada especie. Se aplicaron modelos lineares mixtos entre la eficiencia intrínseca del uso de agua (EIUA) y las variables climáticas. Los resultados muestran una correlación inversa altamente significativa entre $\delta^{13} \mathrm{C}$ y el ancho de los anillos de crecimiento de ambas especies. La humedad del invierno y de la primavera se correlacionan negativamente con la EIUA de Pinus pinaster. La temperatura media máxima de Julio se correlaciona positivamente con EIUA de Pinus sylvestris. Debido a que la $\delta^{13} \mathrm{C}$ está significativamente relacionada con el clima y el crecimiento se puede recomendar como una herramienta de valor para el análisis de la dinámica forestal ante las condiciones climáticas cada vez más estresantes.

Palabras clave: eficiencia intrínseca del uso de agua, pinos mediterráneos, isótopos de carbono, anillo de crecimiento.

\section{INTRODUCTION}

Carbon isotope variability, recorded as ${ }^{13} \mathrm{C} /{ }^{12} \mathrm{C}$ variations in tree rings of woody species, may represent an annual record of physiological tree responses to environment (Francey and Farquhar 1982). Since cellulose is not transferred between annual growth rings, intra and interannual seasonal events are recorded permanently as carbon thirteen variability $\left(\delta^{13} \mathrm{C}\right)$ in tree rings (Tans et al. 1978). $\delta^{13} \mathrm{C}$ depends on stomatal conductance and pho- tosynthesis; when stomatal conductance predominates, relative humidity and soil air moisture are the determining factors. When photosynthetic rate predominates, the main determining factors are solar radiation and temperature (McCarroll and Loader 2004).

The Mediterranean climate is characterized by summer drought and high interannual variability of precipitation and temperature. Species growing in Mediterranean environment show a yearly changing ratio of $\delta^{13} \mathrm{C}$ in each tree ring as a result of variable climate conditions (temperature 
and precipitation); therefore, $\delta^{13} \mathrm{C}$ may provide a strong indicator of climate severity (McCarroll and Loader 2004), effects on gas exchange, water use and secondary growth of tree species (Granda et al. 2014) as well as the long term association among growth, climate and carbon exchange and the tree capacity for coping with severe drought events (Voltas et al. 2013).

Maritime pine (Pinus pinaster Ait.) is a dominant species in Mediterranean forests, mainly located in the Iberian Peninsula (Blanco et al. 1997). This species shows a wide ecological range (Nicolas and Gandullo 1967), as it survives at high or low temperatures, regular or variable rainfall as well as severe droughts. It is adapted to the extremely cold winters of the continental climate in central Spain and to the mild, temperate winters of the Atlantic coast in the western Iberian Peninsula (Alía et al. 1996, Blanco et al. 1997).

Scots pine (Pinus sylvestris L.) is the most widely distributed species of pine in the world (Schweingruber 1996), and in the Iberian Peninsula it occupies drier areas than in the other parts of the world (Barbéro et al. 1998). The primary locations to investigate the effects of increased aridity are drier areas of the distribution of Pinus sylvestris rather than the humid environment where the species more commonly grows (Martínez-Vilalta and Piñol 2002).

In Spain, Pinus pinaster and Pinus sylvestris occupy 1.6 and 1.21 million ha, respectively, as pure or mixed woodlands, and are two of the main species used in operational forestry (DGCN 2002). Previous studies in the Iberian Peninsula determined that $\delta^{13} \mathrm{C}$ in tree rings of Pinus nigra Arnold forests was affected by climate (Granda et al. 2014), whereas $\delta^{13} \mathrm{C}$ in Pinus uncinata Miller, Pinus sylvestris and Pinus nigra was affected by summer rainfall (Andreu et al. 2008). Furthermore, the isotope analysis revealed the vulnerability of Scots pine to winter-drought in its southernmost distribution limit (Voltas et al. 2013). Presently, new studies point out the link between atmospheric changes related to human activities and their impact on isotope records (Saurer and Siegwolf 2007, Silva and Horwarth 2013).

Presently, there is no information about stable carbon isotopes in tree rings of Pinus pinaster growing under Mediterranean climate conditions. Given the high vulnerability of Iberian plant communities to climate change (Bakkenes et al. 2002) and the importance of Pinus pinaster and Pinus sylvestris forests in this region, stable carbon isotope ratios may provide valuable information about both, climate variables that affect growth variability and how $\delta^{13} \mathrm{C}$ is correlated with tree-ring growth and climate. These results may help us to explore how populations behaved in the past and how they will behave under the climatic shifts expected in the future (Andreu et al. 2008).

The objectives of this study are: a) to determine the link between tree-ring growth and $\delta^{13} \mathrm{C}$, and b) to establish the relationship between climate variables (temperature, rainfall and air moisture) and $\delta^{13} \mathrm{C}$ in tree ring of Pinus pinaster and Pinus sylvestris growing in Mediterranean environments. Our hypothesis is that $\delta^{13} \mathrm{C}$ is significantly influenced by climatic variables; hence a high variability of $\delta^{13} \mathrm{C}$ can be expected for both species growing in two sites showing contrasting climates in Mediterranean environments.

\section{METHODS}

Study area and sampled species. Four dated trees of Pinus pinaster from one sampling site (Cuenca) and four dated trees of Pinus sylvestris from another one (Soria) were selected. Samples belonged to two previous dendroclimatological studies (Bogino and Bravo 2008, Bogino et al. 2009; see figure 1, table 1). Detailed explanation of the dendrochronological methods can be found in both studies. Four trees were used as an adequate number of samples providing acceptable average absolute $\delta^{13} \mathrm{C}$ values (McCarroll and Pawellek 1998).

Tree ring isotopes and iWUE analyses. The $\delta^{13} \mathrm{C}$ isotope was determined on whole wood (Schleser et al. 1999, Barbour et al. 2001). Pulverized woody material was obtained for each tree ring with a Micromot $40 \mathrm{E}$ instrument with a $0.5 \mathrm{~mm}$ thick needle. The samples were obtained after identification of the previously dated cores (Bogino and Bravo 2008, Bogino et al. 2009). For each tree ring, 0.2$0.3 \mathrm{mg}$ of pulverized woody material was placed into tin capsules. The stable carbon isotope ratio was determined by combusting the samples with an NA 2500 elemental analyzer (CE Instruments, Rodano, Italy), which was coupled to an isotope ratio mass spectrometer (Finningan MAT Delta plus, Bremen, Germany).

The $\delta^{13} \mathrm{C}$ was determined with the formula [1]:

$\delta^{13} \mathrm{C}(\%)=\left[\left({ }^{13} \mathrm{C} /{ }^{12} \mathrm{C}\right.\right.$ sample $) /\left({ }^{13} \mathrm{C} /{ }^{12} \mathrm{C}\right.$ VPDB -1$\left.)\right] \times 10^{3}$,

where $\delta^{13} \mathrm{C}(\%)$ is the proportional deviation from the international Vienna PeeDee Belemnite (VPDB) carbonate standard (Craig 1957).

Intrinsic water use efficiency (iWUE) was used instead of $\delta^{13} \mathrm{C}_{\text {wood }}$ (\%) as the isotopic carbon ratios $\left({ }^{13} \mathrm{C} /{ }^{12} \mathrm{C}\right)$ in atmospheric $\mathrm{CO}_{2}$ has steadily decreased since the 1960 s due

Table 1.Location, altitude and time span of Pinus pinaster and Pinus sylvestris series used in the isotope analyses.

Ubicación geográfica, altitud y período analizado para las series de Pinus pinaster y Pinus sylvestris usadas en el estudio de isótopos.

\begin{tabular}{lcc}
\hline & Pinus pinaster & Pinus sylvestris \\
\hline Latitude & $39^{\circ} 48^{\prime} 56^{\prime} \mathrm{S}$ & $42^{\circ} 04^{\prime} 36^{\prime} \mathrm{S}$ \\
Longitude & $01^{\circ} 15^{\prime} 36^{\prime \prime} \mathrm{W}$ & $02^{\circ} 30^{\prime} 18^{\prime \prime} \mathrm{W}$ \\
Altitude (m) & 920 & 1,676 \\
Time span & $1947-2005$ & $1945-2005$ \\
\hline
\end{tabular}

Time spam: Chronology longitude (Bogino and Bravo 2008). 


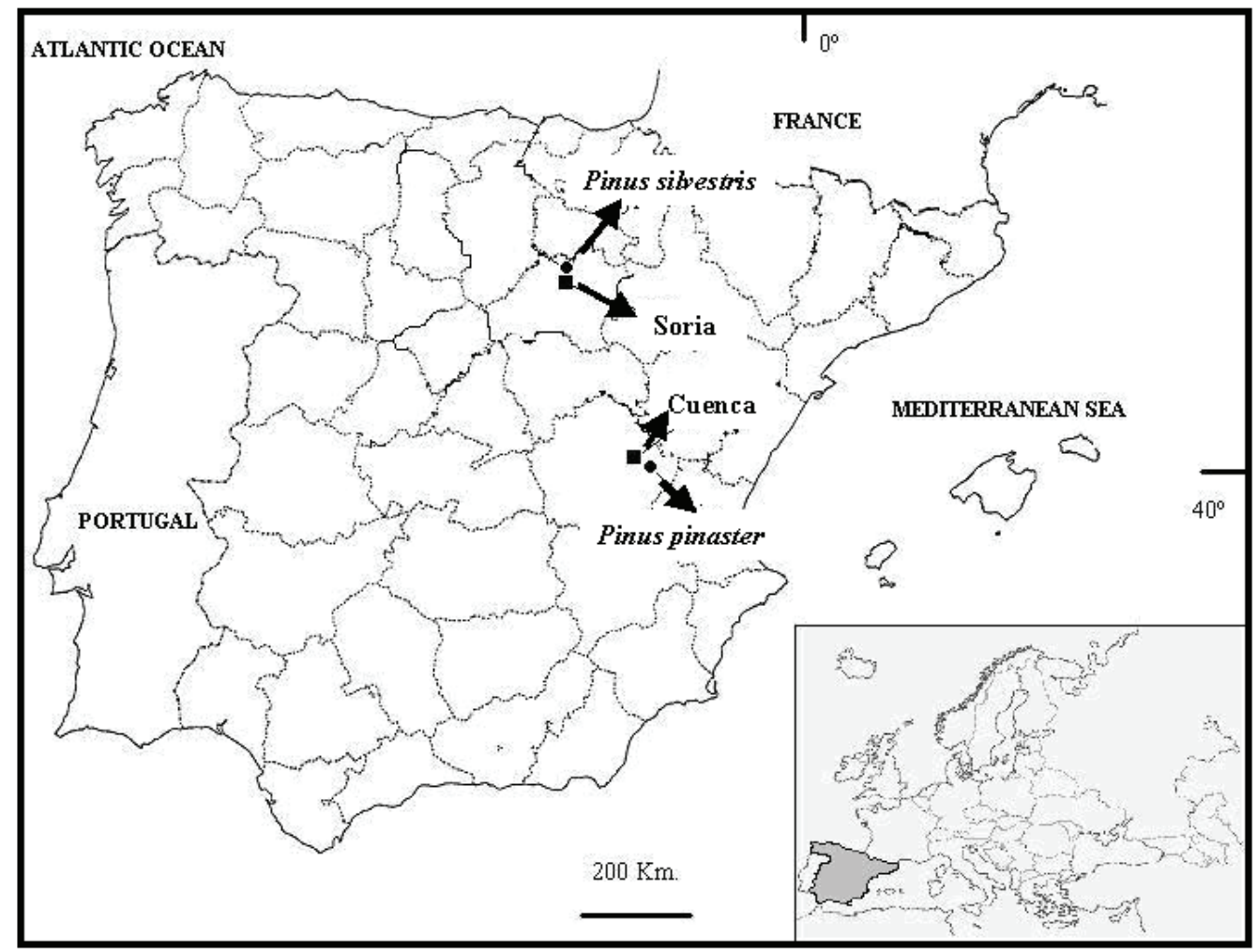

Figure 1. Sampling sites (circles) of Pinus pinaster and Pinus sylvestris and the meteorological stations (squares) Soria and Cuenca in the Iberian Peninsula.

Sitios de muestreo (círculos) de Pinus pinaster y Pinus sylvestris y estaciones meteorológicas (cuadros) Soria y Cuenca en la península Ibérica.

to fossil fuel emissions. To take into account the atmospheric $\delta^{13} \mathrm{C}$ reduction, the isotopic discrimination between atmospheric carbon and plant carbon $(\Delta)$, instead of raw series of $\delta^{13} \mathrm{C}$ in wood, has been used following the methodology proposed by McCarroll and Loader (2004) [2].

$$
\Delta=\left(\delta^{13} \mathrm{C}_{\text {atm }}-\delta^{13} \mathrm{C}_{\text {wood }}\right) /\left(1+\delta^{13} \mathrm{C}_{\text {wood }} / 1000\right)
$$

where $\delta^{13} \mathrm{C}_{\text {atm }}$ and $\delta^{13} \mathrm{C}_{\text {wood }}$ are the isotopic ratios of carbon $\left({ }^{13} \mathrm{C} /{ }^{12} \mathrm{C}\right)$ in atmospheric $\mathrm{CO}_{2}$ and plant material, respectively, expressed in parts per thousand (\%) relative to the standard VPDB.

The relations between tree-ring $\delta^{13} \mathrm{C}$ and tree net carbon assimilation to stomatal conductance of water vapor and the iWUE strong relation with atmospheric $\mathrm{CO}_{2}$ partial pressure and long-term trends in the internal regulation of carbon uptake and water loss in plants led to remove the effect of global atmospheric $\mathrm{CO}_{2}$ increase by using the linear relation between $\Delta$ and the ratio of intercellular $\left(C_{\mathrm{i}}\right)$ to atmospheric $\left(C_{\mathrm{a}}\right) \mathrm{CO}_{2}$ mole fractions (Farquhar et al. 1982) [3]:

$\Delta=a+(b-a) C_{\mathrm{i}} / C_{\mathrm{a}}$

where $a$ is the fractionation during $\mathrm{CO}_{2}$ diffusion through the stomata equal to $4.4 \%$ (O'Leary 1981), and $b$ is the fractionation associated with reactions by Rubisco and PEP carboxylase equal to 27 \%o (Farquhar and Richards 1984). Values for $C_{\mathrm{a}}$ and $\delta^{13} \mathrm{C}_{\text {atm }}$ were obtained from McCarroll and Loader (2004).

Finally, the $C_{\mathrm{i}} / C_{\mathrm{a}}$ ratio reflects the balance between net assimilation $(A)$ and stomatal conductance for $\mathrm{CO}_{2}\left(g_{c}\right)$ according to Fick's law: $A=g_{\mathrm{c}}\left(C_{\mathrm{a}}-C_{\mathrm{i}}\right)$. Stomatal conductance for $\mathrm{CO}_{2}$ and water vapor $\left(g_{\mathrm{w}}\right)$ is related by a constant factor $\left(g_{\mathrm{w}}=1.6 g_{\mathrm{c}}\right)$, thus linking the leaf gas exchange of carbon and water. The linear relationship between $C_{\mathrm{i}} / C_{\mathrm{a}}$ and $\Delta$ can be used to calculate the intrinsic water use efficiency, WUEi $=A / g_{w}[4]$

$$
\mathrm{WUEi}=c_{\mathrm{a}}(b-\Delta) /[1.6(b-a)]
$$

The period 1975-1999 was analyzed. This period was selected as previous studies showed both, a changing relationship between climate variables and tree-ring growth of Pinus pinaster from the 1980s onwards (Bogino and Bravo 2008) as well as phenological changes in both species over the last 25 years (Peñuelas et al. 2002, Andreu et al. 2008, Granda et al. 2014).

Statistical analyses. Principal component analysis (PCA) was applied among all trees of both species to detect com- 
mon patterns in $\delta^{13} \mathrm{C}$ and between $\delta^{13} \mathrm{C}$ and the residual tree-ring chronologies (data from Bogino and Bravo 2008, Bogino et al. 2009) to detect a significant association between growth and $\delta^{13} \mathrm{C}$. Residual tree-ring chronology is the difference between predicted and estimate values obtained by applying a given function to the data set (Fritts 1976). Pearson's correlation coefficient was used between $\delta^{13} \mathrm{C}$ and monthly climatic variables (monthly air moisture, monthly precipitation and mean monthly maximum temperature) to estimate which environmental variables were statistically significant.

Climate data from Cuenca and Soria meteorological stations of the Agencia Estatal de Meteorología, Spain were used (table 2). Climate diagrams are included (figure 2). The software used in the statistical analyses was Infostat version 2008 (Di Rienzo et al. 2008).

Radial increments of tree rings are a set of longitudinal growth data, which imply that observations from the same tree could be largely correlated. Consequently, to avoid estimation problems a multilevel linear mixed model was used to determine the climate variables that influence iWUE in each tree ring. Each species was analyzed independently, iWUE in tree ring was considered as a random variable, while climate was considered as a fixed variable. The formula was [5]

$$
\mathrm{Y}_{\mathrm{k}}^{(\mathrm{t})}=\beta_{0}+\sum_{\mathrm{i}} \beta_{\mathrm{k}} *\left(\mathrm{X}_{\mathrm{i}}\right)_{\mathrm{k}}^{(\mathrm{t})}+\chi_{\mathrm{k}}+\varepsilon_{\mathrm{k}}^{(\mathrm{t})}
$$

where $Y_{k}^{(t)}$ is the logarithm of $-1 *$ iWUE for the tree $\boldsymbol{k}$ in the year $\boldsymbol{t} ; \beta_{0}$ is the independent term; $\beta_{\mathrm{k}}$ is the parameter associate to tree $\boldsymbol{k}$ and climate variable $i$ and $\left(\mathrm{X}_{\mathrm{i}}\right)_{\mathrm{k}}^{(\mathrm{t})}$ are the climate variables for each $\boldsymbol{k}$ tree in the year $\boldsymbol{t} ; \gamma_{K}$ is the tree random effect and $\varepsilon_{\mathrm{k}}^{(\mathrm{t})}$ is the random error of the tree $\boldsymbol{k}$ in the year $\boldsymbol{t}$.

Based on an exploratory analysis using Pearson's correlation coefficient between $\delta^{13} \mathrm{C}$ and monthly climate variables, from January to December of the growing season, six additive combinations of independent variables $\left(X_{i}\right)$ were used for both species (Models 1 to 6 ) and two additional models only for P. sylvestris (Models 7 and 8):

Model 1: Winter Precipitation + Spring Precipitation + Summer Precipitation + Fall Precipitation

Model 2: Winter Precipitation + Spring Precipitation

Model 3: Spring Precipitation + Fall Precipitation

Table 2. Descriptive statistic of climate variables of Cuenca and Soria Meteorological Stations (1975-1999 period). Estadística descriptiva de las variables climáticas de las estaciones meteorológicas de Cuenca y Soria (período 1975-1999).

\begin{tabular}{lcccc}
\hline \multicolumn{1}{c}{ Variable } & Mean & SD & Min & Max \\
\hline Mean annual rainfall , Cuenca $(\mathrm{mm})$ & 500.3 & 119.4 & 266.2 & 700.6 \\
Mean annual maximum temperature, Cuenca $\left({ }^{\circ} \mathrm{C}\right)$ & 18.8 & 0.7 & 17.7 & 20.1 \\
Mean annual relative humidity, Cuenca $(\%)$ & 62.7 & 3.0 & 57.2 & 69.5 \\
Mean annual rainfall , Soria (mm) & 505.8 & 102.9 & 370.4 & 859.6 \\
Mean annual maximum temperature, Soria $\left({ }^{\circ} \mathrm{C}\right)$ & 16.8 & 0.7 & 15.6 & 18.0 \\
Mean annual relative humidity, Soria $(\%)$ & 67.7 & 3.4 & 61.0 & 73.8 \\
\hline
\end{tabular}
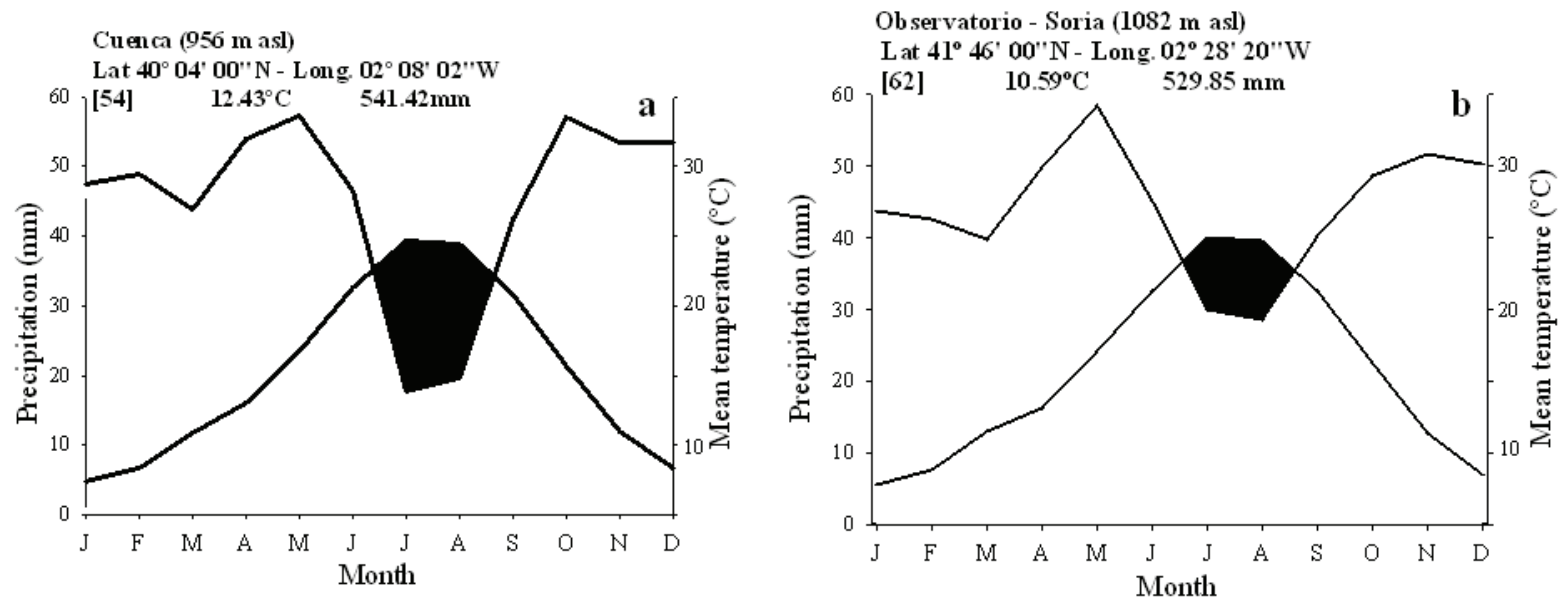

Figure 2. Climate diagram of Cuenca (a) and Observatorio Soria (b) meteorological stations. Diagrama climático de las estaciones meteorológicas de Cuenca (a) y Soria (b). 
Model 4: Winter Air Moisture + Spring Air Moisture + Summer Air Moisture + Fall Air Moisture

Model 5: Winter Air Moisture + Spring Air Moisture

Model 6: Spring Air Moisture + Fall Air Moisture

Model 7: July maximum mean temperature

Model 8: January maximum mean temperature

The tree random effect $\delta_{\mathrm{k}} \rightarrow \mathrm{N}\left(0, \sigma_{\delta}^{2}\right)$ and the random error $\varepsilon_{\mathrm{k}}$ were considered as independently distributed $N\left(0, \Sigma_{k}\right)$, where $\Sigma_{k}$ is an autoregressive error type 1 variance-covariance matrix (with multiple observations on individual autocorrelated trees over time). The significance of the variables was determined using the $P$-value parameter $(P<0.05)$ and their biological behavior. Models were selected using the Akaike's information criterion (AIC), the Bayesian information criteria (BIC) and the statistic -2 times logarithm of the likelihood function (-2LL). AIC was corrected considering the low number of samples (100 samples for each tree species). PROC MIXED in SAS (SAS Institute Inc. 2004) was used to fit the models.

\section{RESULTS}

Average isotope values. Mean values that characterized each tree-ring $\delta^{13} \mathrm{C}$ of both species in each analyzed year showed that Pinus pinaster had the highest and the lowest $\delta^{13} \mathrm{C}$ values (-22.62 \%o and -25.87\%o), whereas for $\mathrm{Pi}$ nus sylvestris these values varied between -23.85 \%o and $-25.80 \%$ (figure 3 ).

Mean values that characterized the eight trees are shown in table 3. Pinus sylvestris showed S.D. lower than $1 \%$, whereas Pinus pinaster showed higher variability throughout the 25 year period ( $\mathrm{SD}=1.41$, tree 48 ).

Relationships among $\delta^{13} \mathrm{C}$, growth and climate. PCA shows an opposite distribution of residual tree-ring chronologies and $\delta^{13} \mathrm{C}$. Conversely, $\delta^{13} \mathrm{C}$ of the same species is grouped suggesting a common $\delta^{13} \mathrm{C}$ variability pattern. The $72 \%$ of the variability was explained by the two first eigenvalues (figure 4).

Pearson's correlation coefficient from the PCA between trees of the same species showed a positive significant correlation in Pinus pinaster and Pinus sylvestris. Only trees 4 and 8 of Pinus sylvestris did not show a significant correlation (table 4).

A negative significant correlation was detected between $\delta^{13} \mathrm{C}$ and tree-ring growth. Pearson's correlation coefficient between the residual tree-ring chronology and the mean $\delta^{13} \mathrm{C}$ was $\mathrm{r}=-0.83(* * *=P<0.001)$ for Pinus pinaster and $\mathrm{r}=-0.41(*=P<0.05)$ for Pinus sylvestris.

Pearson's correlation coefficient between climate variables and $\delta^{13} \mathrm{C}$ of Pinus pinaster showed that air moisture

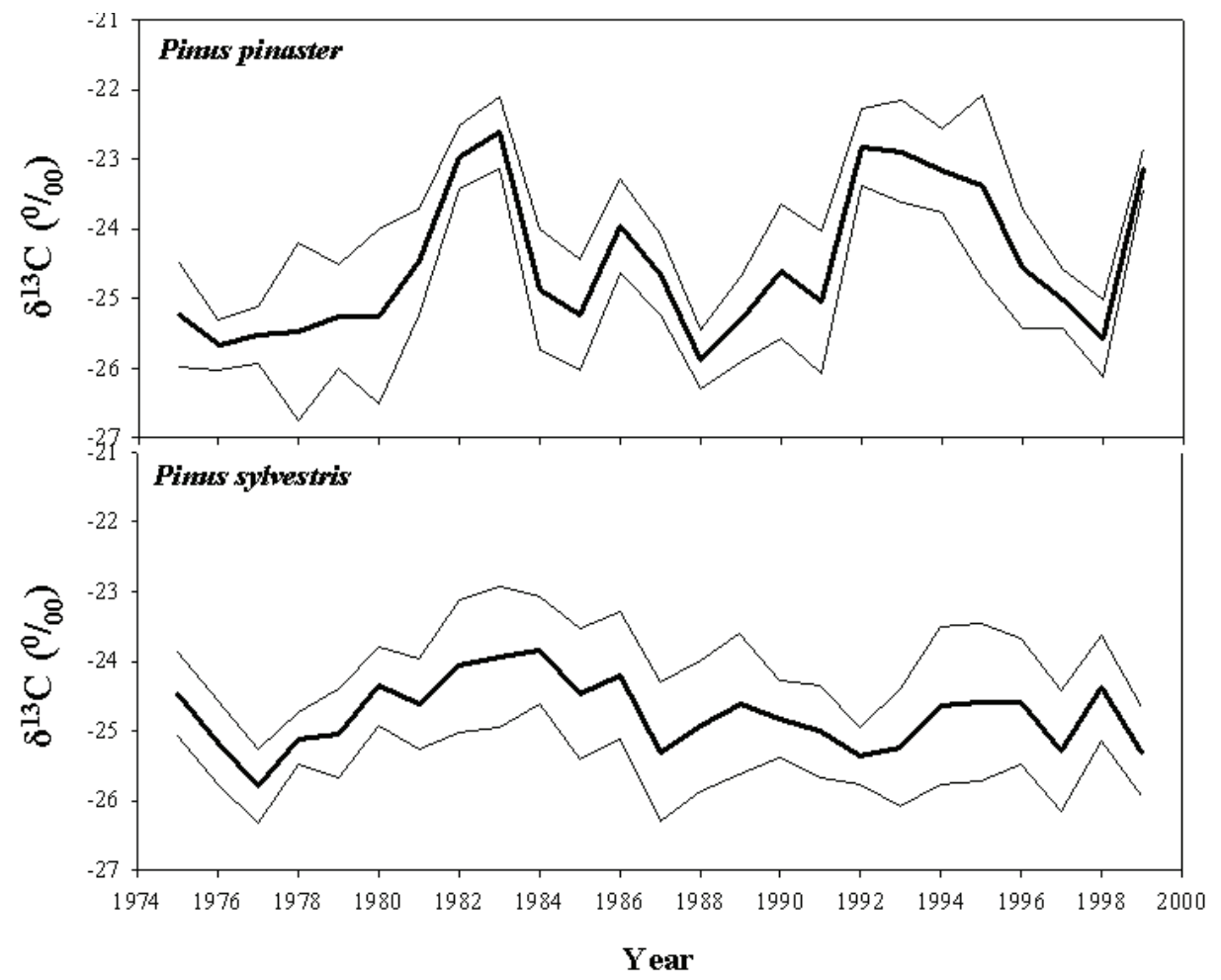

Figure 3. Mean values (thick lines) and confident interval at $95 \%$ (thin lines) of isotope analyses for Pinus pinaster and Pinus sylvestris in central Spain.

Valores medios (líneas gruesas) e intervalos de confianza al 95 \% (líneas finas) del análisis de isótopos de Pinus pinaster y Pinus sylvestris en el centro de España. 
Table 3. Descriptive statistic of the four individuals of Pinus pinaster and Pinus sylvestris used in the isotope analyses in central Spain. Estadística descriptiva de los cuatro individuos de Pinus pinaster y Pinus sylvestris usados en el análisis de isótopos en el centro de España.

\begin{tabular}{|c|c|c|c|c|c|}
\hline Tree & $\mathrm{n}$ & Mean (\%о) & SD (\%) & Min. (\%o) & Max. (\%о) \\
\hline \multicolumn{6}{|c|}{ Pinus pinaster } \\
\hline Tree 48* & 25 & -24.52 & 1.41 & -27.07 & -22.2 \\
\hline Tree 44 & 25 & -25.03 & 1.23 & -27.10 & -23.07 \\
\hline Tree 27 & 25 & -23.89 & 0.96 & -25.61 & -22.07 \\
\hline Tree 53 & 25 & -24.58 & 1.06 & -26.05 & -22.40 \\
\hline \multicolumn{6}{|c|}{ Pinus sylvestris } \\
\hline Tree 23 & 25 & -25.79 & 0.48 & -26.65 & -24.91 \\
\hline Tree 19 & 25 & -24.23 & 0.78 & -25.75 & -22.85 \\
\hline Tree 8 & 25 & -24.45 & 0.55 & -25.51 & -23.57 \\
\hline Tree 4 & 25 & -24.6 & 0.58 & -25.79 & -23.2 \\
\hline
\end{tabular}

*For more information about selected trees, see Bogino and Bravo (2008); n: number of analyzed tree rings; Mean: Average $\delta^{13} \mathrm{C}$ of each tree; SD: Standard deviation of $\delta^{13} \mathrm{C}$ in each tree; Min and Max values of $\delta^{13} \mathrm{C}$ in each tree

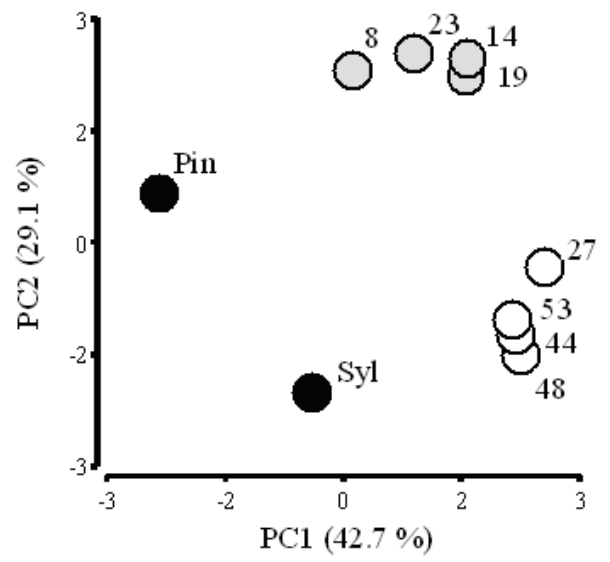

Figure 4. Principal component analysis (PCA) of residual treering chronologies of Pinus pinaster (Pin) and Pinus sylvestris (Syl) and $\delta^{13} \mathrm{C}$ in each tree. White circles belong to Pinus pinaster $\delta^{13} \mathrm{C}$, grey circles to Pinus sylvestris $\delta^{13} \mathrm{C}$ and black circles to the residual tree-ring chronologies of both species. The numbers identify each tree.

Análisis de componentes principales (ACP) de las cronologías residuales de ancho de anillos de Pinus pinaster (Pin) y Pinus sylvestris (Syl) y $\delta^{13} \mathrm{C}$ de cada árbol. Los círculos blancos pertenecen a la $\delta^{13} \mathrm{C}$ de Pinus pinaster, los círculos grises a la $\delta^{13} \mathrm{C}$ de Pinus sylvestris y los círculos negros a las cronologías residuales de ambas especies. Los números identifican a cada árbol.

negatively affects ${ }^{13} \mathrm{C} /{ }^{12} \mathrm{C}$ variability from winter to summer (January to July) (figure 5A). Also, rainfall showed a negative effect on $\delta^{13} \mathrm{C}$ from winter to springtime but was statistically significant only in April and May (figure 5B). Monthly mean maximum temperature in March showed a positive significant effect on $\delta^{13} \mathrm{C}$ (figure 5C).

Pearson's correlation coefficient between climate variables and $\delta^{13} \mathrm{C}$ of Pinus sylvestris showed that air mois-
Table 4. Pearson's correlation coefficient involving carbon thirteen variability $\left(\delta^{13} \mathrm{C}\right)$ in trees of Pinus pinaster and Pinus sylvestris.

Coeficiente de correlación de Pearson entre la variabilidad del carbono trece $\left(\delta^{13} \mathrm{C}\right)$ de los árboles de Pinus pinaster y Pinus sylvestris.

\begin{tabular}{llcc}
\hline \multicolumn{4}{c}{ Pinus pinaster } \\
\hline & Tree 48 & Tree 44 & Tree 27 \\
\hline Tree 44 & $0.82^{* * *}$ & - & - \\
Tree 27 & $0.8^{* * *}$ & $0.73^{* * *}$ & - \\
Tree 53 & $0.68^{* * *}$ & $0.7^{* * *}$ & $0.73^{* * *}$ \\
\hline \multicolumn{4}{c}{ Pinus sylvestris } \\
\hline Tree 19 & Tree 23 & Tree 9 & Tree 8 \\
Tree 8 & $0.59^{* * *}$ & - & - \\
Tree 4 & $0.41 *$ & $0.5 * *$ & - \\
\hline
\end{tabular}

$*=P<0.05 ; * *=P<0.01 ; * * *=P<0.001$, correlation with asterisks are significant.

ture negatively affected ${ }^{13} \mathrm{C} /{ }^{12} \mathrm{C}$ variability in July and in October (figure 6A). Also, rainfall in October showed a negative effect on $\delta^{13} \mathrm{C}$ (Figure 6B). Monthly mean maximum temperature in summer (June and July) showed a positive significant effect on $\delta^{13} \mathrm{C}$ (figure 6C).

Relationships among iWUE and climate. Following the criteria model selection, model 5 was selected for Pinus pinaster and model 7 was selected for Pinus sylvestris (table 5). Most of the Pinus pinaster trees show significant relationship between iWUE and winter and spring air moisture. July maximum temperature has a significant influence on iWUE in all Pinus sylvestris trees (table 6). 

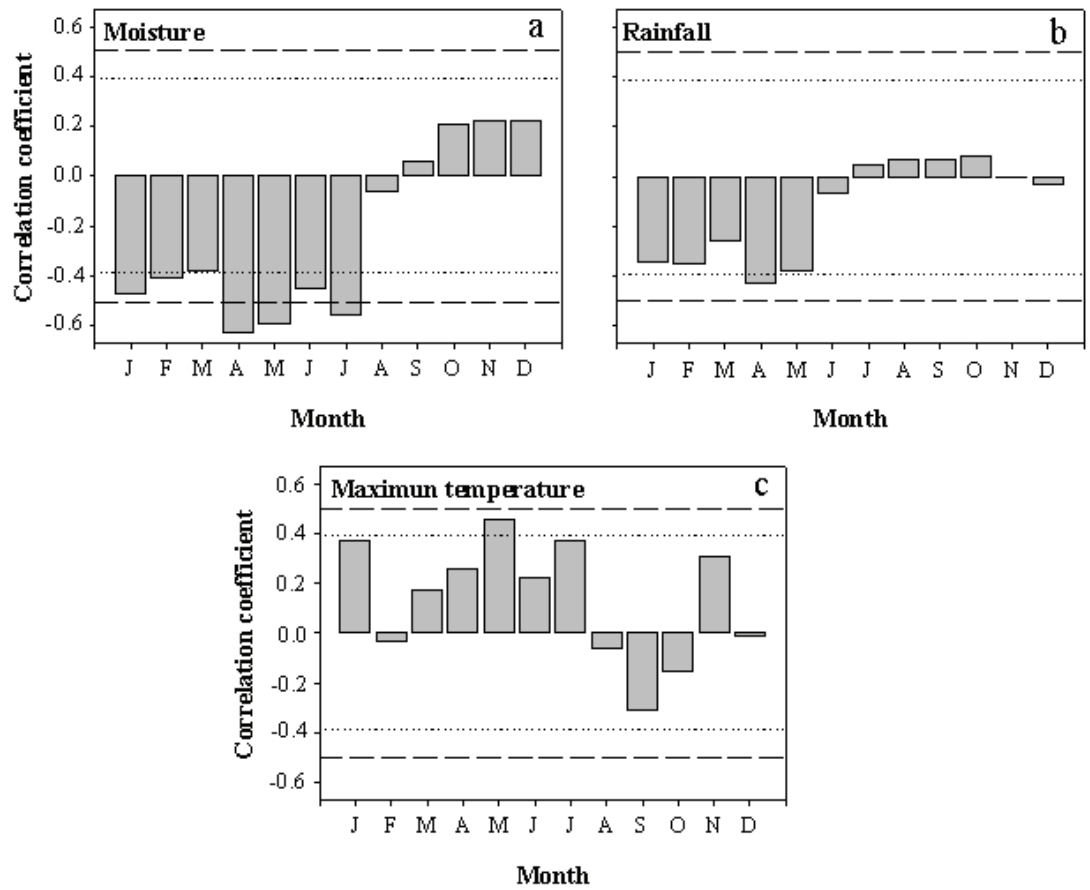

Figure 5. Pearson's correlation coefficients between $\delta^{13} \mathrm{C}$ of Pinus pinaster and mean monthly air moisture (A), monthly rainfall (B) and maximum mean monthly temperature. Bars outside dashed lines show significant coefficients at $* *=P<0.01$. Bars outside dotted lines show significant coefficients at $*=P<0.05$.

Coeficiente de correlación de Pearson entre la $\delta^{13} \mathrm{C}$ de Pinus pinaster y la humedad mensual media del aire (A), la lluvia mensual (B) y la temperatura máxima media mensual. Las barras superiores a las líneas cortadas muestran coeficientes significativos a $* *=P<0,01$. Las barras superiores a las líneas de puntos muestran coeficientes significativos a $*=P<0,05$.
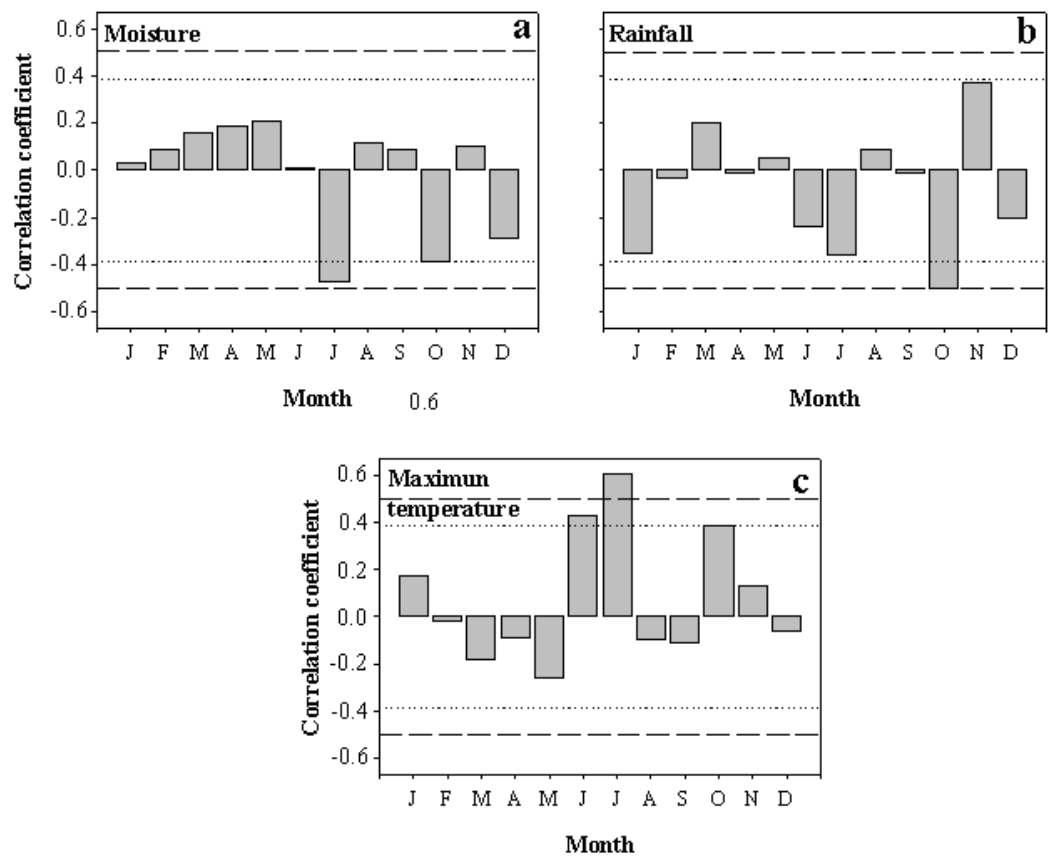

Figure 6. Pearson's correlation coefficients between $\delta^{13} \mathrm{C}$ isotopes of Pinus sylvestris and mean monthly air moisture (A), monthly rainfall (B) and maximum mean monthly temperature (C). Bars outside dashed lines show significant coefficients at $* *=P<0.01$. Bars outside dotted lines show significant coefficients at $*=P<0.05$.

Coeficiente de correlación de Pearson entre la $\delta^{13} \mathrm{C}$ de Pinus sylvestris y la humedad media mensual del aire (A), la lluvia mensual (B) y la temperatura máxima media mensual. Las barras superiores a las líneas cortadas muestran coeficientes significativos a $* *=P<0,01$. Las barras superiores a las líneas de puntos muestran coeficientes significativos a $*=P<0,05$. 
Table 5. Model selection procedure for intrinsic water use efficiency (iWUE) of trees of Pinus pinaster and Pinus sylvestris in central Spain. Modelos seleccionados para eficiencia en el uso intrínseco del agua (EUIA) de los árboles de Pinus pinaster y Pinus sylvestris en el centro de España.

\begin{tabular}{|c|c|c|c|c|c|}
\hline \multirow[t]{2}{*}{ Model } & AR(1) Estimator & \multirow{2}{*}{$-2 \mathrm{LL}$} & \multirow{2}{*}{ AICc } & \multirow{2}{*}{ BIC } & \multirow{2}{*}{$\begin{array}{c}\text { Mixed model } \\
\operatorname{Pr}<\text { chi-squared }\end{array}$} \\
\hline & (residual) & & & & \\
\hline \multicolumn{6}{|c|}{ Pinus pinaster } \\
\hline Model 1 & $0.3551(0.0412)$ & 219.6 & 223.8 & 222.4 & 0.0103 \\
\hline Model 2 & $0.3560(0.0389)$ & 87.4 & 91.5 & 90.2 & 0.0008 \\
\hline Model 3 & 0.4099 (0.0438) & 95.6 & 99.7 & 98.4 & $<0.0001$ \\
\hline Model 4 & $0.3276(0.0333)$ & 98.7 & 102.9 & 101.5 & 0.0047 \\
\hline Model 5 & $0.3861(0.0341)$ & 23.8 & 27.9 & 26.6 & 0.0002 \\
\hline Model 6 & $0.3553(0.0349)$ & 30.1 & 34.2 & 32.9 & 0.0009 \\
\hline \multicolumn{6}{|c|}{ Pinus sylvestris } \\
\hline Model 1 & $0.5782(0.0187)$ & 135.9 & 140.0 & 138.7 & $<0.0001$ \\
\hline Model 2 & 0.5039 (0.0212) & 17.0 & 21.2 & 19.8 & $<0.0010$ \\
\hline Model 3 & $0.5090(0.0170)$ & -2.4 & 1.7 & 0.4 & $<0.0010$ \\
\hline Model 4 & $0.5074(0.0170)$ & 23.5 & 27.7 & 26.3 & $<0.0001$ \\
\hline Model 5 & $0.4299(0.0154)$ & -54.8 & -50.7 & -52.1 & $<0.0001$ \\
\hline Model 6 & $0.4260(0.0164)$ & -46.3 & -42.2 & -43.6 & 0.0001 \\
\hline Model 7 & $0.6318(0.0194)$ & -119.7 & -115.5 & -116.9 & $<0.0001$ \\
\hline Model 8 & $0.5069(0.0191)$ & -107.5 & -103.3 & -104.7 & $<0.0001$ \\
\hline
\end{tabular}

-2LL: -2 times logarithm of the likelihood function, AIC: Akaike’s information criterion and BIC: Bayesian information criteria.

Table 6. Selected models for intrinsic water use efficiency (iWUE) of trees of Pinus pinaster and Pinus sylvestris in central Spain.

Modelos seleccionados para eficiencia en el uso intrínseco del agua (EUIA) de los árboles de Pinus pinastery Pinus sylvestris en el centro de España.

\begin{tabular}{lcc}
\hline & Parameter estimator & $P$-value \\
\hline \multicolumn{3}{c}{ Pinus pinaster } \\
\hline Intercept & -1.2821 & 0.0169 \\
\hline Winter moisture & & \\
\hline Tree 27 & 0.001914 & 0.2830 \\
Tree 44 & 0.003226 & 0.0721 \\
Tree 48 & 0.002707 & 0.1301 \\
Tree 53 & 0.003588 & 0.0459 \\
\hline Spring moisture & & \\
\hline Tree 27 & 0.005565 & 0.0069 \\
Tree 44 & 0.005138 & 0.0123 \\
Tree 48 & 0.005288 & 0.0101 \\
Tree 53 & 0.004304 & 0.0351 \\
\hline & Pinus sylvestris \\
\hline Intercept & 1.0284 & 0.0070 \\
\hline July max temp & & $<0.0001$ \\
\hline Tree 4 & -0.02813 & $<0.0001$ \\
Tree 18 & -0.02828 & $<0001$ \\
Tree 19 & -0.03096 & \\
Tree 23 & -0.02152 & \\
\hline & & \\
\hline
\end{tabular}

\section{DISCUSSION}

Contrasting climate and growth signals on $\delta^{13} \mathrm{C}$ in tree rings of Pinus pinaster and Pinus sylvestris were found over time among the analyzed Mediterranean forests of central Spain.

The individual tree response in relation to fractionation (the ratio of carbon isotope ratios in reactant and products) (Farquhar et al. 1989) was clear in this study, where different trees in the same calendar year showed a high variability of $\delta^{13} \mathrm{C}$, which varied from $-24.11 \%$ o to $-27.10 \%$ (year 1978) and from-23.43\% to - $26.12 \%$ o (year 1994) in Pinus pinaster and Pinus sylvestris, respectively. The highest values of $\delta^{13} \mathrm{C}$ of Pinus sylvestris highlight previous studies that concluded that species growing at higher altitudinal positions have less $\delta^{13} \mathrm{C}$ discrimination than that presented by trees growing at lower sites (Fernandez et al. 2005). The variability in $\delta^{13} \mathrm{C}$ between species growing in the same area in Mediterranean environments showed opposite iWUE under severe drought events (Granda et al. 2014) and our results emphasized that this variability was detected between and within the species.

The inverse significant association between $\delta^{13} \mathrm{C}$ and tree-ring width of Pinus pinaster and Pinus sylvestris emphazises that both variables are affected by the similar driving environmental factors, thus, $\delta^{13} \mathrm{C}$ can be used to predict residual tree-ring width and vice versa (Andreu et al. 2008). Results showed a highly significant correlation between $\delta^{13} \mathrm{C}$ signal of Pinus pinaster trees and a significant correlation between $\delta^{13} \mathrm{C}$ signal of Pinus sylvestris trees, ex- 
cept for two individuals, which underline the previous statements suggesting that species growing in variable environments show a changing ratio of ${ }^{13} \mathrm{C} /{ }^{12} \mathrm{C}$ in each tree ring as a result of the variable climate conditions (high temperature and low precipitation) (Porté and Loustau 2001). $\delta^{13} \mathrm{C}$ provides a strong indicator of the intensity of these climate variables in this site (McCarroll and Loader 2004) being the long term tendency among iWUE, growth and climate a clear signal of drought causing death in trees growing in Mediterranean environments (Voltas et al. 2013)

Positive air moisture association with iWUE in Pinus pinaster and negative maximum temperature association with iWUE in Pinus sylvestris confirm the hypothesis that $\delta^{13} \mathrm{C}$ of conifers worldwide is an indicator of drought stress in arid and semiarid environments (Warren et al. 2001), which include the Iberian Peninsula (Andreu et al. 2008, Sanchez-Salguero et al. 2012).

De Micco et al. (2007) suggest that Pinus pinaster growing under maritime climatic conditions did not show any strong $\delta^{13} \mathrm{C}$ differences among different years, although a severe drought occurred during the summer of 2001; consequently, they concluded that a stable carbon analysis may not be useful to assess the severity of drought in those environments characterized by seasonal aridity, being site conditions a limiting factor that determines $\delta^{13} \mathrm{C}$ (Candel-Perez et al. 2012). Even though we analyzed the same species, our results showed that Pinus pinaster is an accurate tool for studying climatic conditions recorded as $\delta^{13} \mathrm{C}$ (Porté and Loustau 2001) supporting previous studies which concluded that the same species may have different isotopic response growing in different environments (Sternberg and DeNiro 1983, Leavitt and Long 1984).

The association between climatic and different dendrochronological variables (tree-ring width, intraanual density fluctuation (IADFs) and carbon isotopes) of Pinus pinaster and Pinus sylvestris may provide an excellent instrument to understand the growth dynamics of the species under changing climatic conditions (Bogino and Bravo 2008, 2009, Bogino et al. 2009). In some cases isotopes may have a better correlation with climatic variables than it has with tree-ring width (Andreu et al. 2008), although one proxy does not limit the use of others. For example in sub-fossil chronologies of Pinus sylvestris in Finland, the use of $\delta^{13} \mathrm{C}$ could be limited for climatic reconstruction if it is not used with other proxies (McCarroll and Pawellek 2001).

To summarize, Pinus pinaster and Pinus sylvestris growing in Mediterranean environments show a strong $\delta^{13} \mathrm{C}$ signal, which allows us to detect a) an individual tree response to the local environment conditions, b) a physiological inverse association between $\delta^{13} \mathrm{C}$ and growth, and c) a significant association with climate variables.

\section{ACKNOWLEDGEMENTS}

The authors thank Cristotal Ordóñez for field assistance, María José Fernández Nieto for providing meteorolo- gical data and two anonymous referees for improving the quality of the manuscript. Thanks are also extended to Jens Dyckmans and Reinhard Langel of the Büsgen-Institut Kompetenzzentrum Stabile Isotope (KOSI) Georg-August Universität Göttingen, for their help with the isotope analyses and Gabriela Kitokova for improving the English version. This study was supported by the Regional Castilla y León government of Spain (Project Code VA096A05), the Spanish Ministry of Science and Education (Project Code AGL2007-65795-C02-01) and by the Alßan Programme, the European Union Programme of High Level Scholarships for Latin America (Scholarship \# E05D049920AR).

\section{REFERENCES}

Alía M, Martín S, J De Miguel, R Galera, D Agúndez, J Gordo, G Catalán, L Gil. 1996. Regiones de procedencia Pinus pinaster Ait. Madrid, Spain. DGCONA. 75 p.

Andreu L, O Planells, E Gutiérrez, G Helle, G Schleser. 2008. Climatic significance of tree-ring width and $\delta^{13} \mathrm{C}$ in a Spanish pine forest network. Tellus 60:771-781.

Bakkenes M, J Alkemade, F Ihle, R Leemansand, J Latour. 2002. Assessing effects of forecasted climate change on the diversity and distribution of European higher plants for 2050. Global Change Biology 8: 390-407.

Barbéro M, R Loisel, P Quezel. 1998. Pines of the Mediterranean Basin. In Richardson DM ed.: Pinus. Ecology and Biogeography of Pinus. Cambridge, UK. Cambridge University Press. p.153-170.

Barbour M, J Andrews, G Farquhar. 2001. Correlations between oxygen isotope ratios of wood constituents of Quercus and Pinus samples from around the world. Austral Journal of Plant Physiology 28: 335-348.

Blanco E, M Casado, M Costa, R Escribano, M García Antón, M Génova, G Gómez Manzaneque, F Gómez Manzanaque, J Moreno, C Morla, P Regato, H Sainz Ollero. 1997. Los bosques ibéricos. Barcelona, España. Editorial Planeta. 572 p.

Bogino S, F Bravo. 2008. Growth response of Pinus pinaster Ait. to climatic variables in central Spanish forests. Annals of Forest Science 65: 506-518.

Bogino S, F Bravo. 2009 Climate and intraannual density fluctuations in Pinus pinaster subsp. mesogeensis in Spanish woodlands. Canadian Journal of Forest Research 39:1557-1565.

Bogino S, M Fernández Nieto, F Bravo. 2009. Drought index and radial growth of Pinus sylvestris $\mathrm{L}$. in its southern and western distribution threshold. Silva Fennica 43: 609-623.

Candel-Pérez D, JC Linares, B Viñegla, ME Lucas-Borja. 2012. Assessing climate growth relationships under contrasting stands of co-occurring Iberian pines along an altitudinal gradient. Forest Ecology and Management 274. 48-57

Craig H. 1957. Isotopic standards for carbon and oxygen and correction factors for mass spectrometric analysis of carbon dioxide. Geochimical Cosmochimical Acta 12: 133-149.

De Micco V, M Saurer, G Aronne, R Tognetti, P Cherubini P. 2007. Variations of wood anatomy and $\delta^{13} \mathrm{C}$ within-tree rings of coastal Pinus pinaster showing intra-annual density fluctuations IAWA Journal 28: 61-74.

DGCN (Dirección Nacional de Conservación de la Naturaleza, ES). 2002. Plan Forestal Español. Madrid, España. Minis- 
terio de Medio Ambiente. 139 p.

Di Rienzo J, M Balzarini, F Casanoves, L Gonzalez, E Tablada, C Robledo. 2013. Infostat Software Estadístico versión 8. Grupo infoStat, FCA. Córdoba, Argentina. Universidad Nacional de Córdoba.

Farquhar GD, H O’Leary, J Berry. 1982. On the relationship between carbon isotope discrimination and the intercellular carbon dioxide concentration in leaves. Austral Journal of Plant Physiology 9: 121-137.

Farquhar GD, R Richards. 1984. Isotopic composition of plant carbon correlates with water-use efficiency of wheat genotypes. Austral Journal of Plant Physiology 11: 539-552.

Farquhar G, J Ehleringer, K Hubick. 1989. Carbon isotope discrimination and photosynthesis. Annual Review of Plant Biology 40: 503-537.

Fernandez I, SJ González-Prieto, A Cabaneiro. 2005. ${ }^{13} \mathrm{C}$-isotopic fingerprint of Pinus pinaster Ait. and Pinus sylvestris L. wood related to the quality of standing tree mass in forests from NW Spain. Rapid Communication in Mass Spectrometry 19(22): 3199-206.

Francey R, G Farquhar G. 1982. An explanation of ${ }^{13} \mathrm{C} /{ }^{12} \mathrm{C}$ variations in tree rings. Nature 297: 28-31.

Fritts H. 1976. Tree Ring and Climate. London, UK. Academic Press. 567 p.

Granda E, D R Rossatto, JJ Camarero, J Voltas, F Valladares. 2014. Growth and carbon isotopes of Mediterranean trees reveal contrasting responses to increased carbon dioxide and drought. Oecologia 174: 307-317. doi: 10.1007/s00442013-2742-4.

Leavitt S, A Long. 1984. Sampling strategy for stable carbon isotope analysis of tree rings in pine. Nature 311: 145-147.

Loader N J, I Robertson, D McCarroll. 2003. Comparison of stable carbon isotope ratios in the whole wood cellulose and lignin of oak tree-rings. Palaeogeology Palaeoclimatology Palaeoecology 196: 395-407.

Martínez-Vilalta J, J Piñol. 2002. Drought-induced mortality and hydraulic architecture in pine populations of the NE Iberian Peninsula. Forest Ecology and Management 161: 247-256.

McCarroll D, F Pawellek. 1998. Stable carbon isotope ratios of latewood cellulose in Pinus sylvestris from northern Finland: variability and signal-strength. The Holocene 8: 675-684.

McCarroll D, F Pawellek. 2001. Stable carbon isotope ratios of Pinus sylvestris from northern Finland and the potential for extracting a climate signal from long Fennoscandian chronologies. The Holocene 11: 517-526.

McCarroll D, N Loader. 2004. Stable isotopes in tree rings. Qua- ternary Science Review 23: 771-801.

Nicolas A, J Gandullo. 1967. Ecología de los pinares españoles. 1 Pinus pinaster Ait. Madrid, España. Ministerio de Agricultura.

O’Leary M H. 1981. Carbon isotope fractionation in plants. Phytochemistry 20: 553-567.

Peñuelas J, I Fillela, P Comas. 2002. Change plant and animal life cycles from 1952 to 2000 in the Mediterranean region. Global Change Biology 8: 531-544.

Porté A, D Loustau. 2001. Seasonal and interannual variations in carbon isotope discrimination in a maritime pine (Pinus pinaster) stand assessed from the isotopic composition of cellulose in annual rings. Tree Physiology 21, 861-868.

Sanchez-Salguero R, RM Navarro-Cerillo, JJ Camarero, A Fernández-Cancio. 2012. Selective drought-induced decline of pine species in southeastern Spain. Climatic Change 113: 767-785.

SAS Institute Inc. 2004. SAS/STAT user’s guide, version 9.1 edition. SAS Institute Inc., Cary, N.C.

Saurer M, RTW Siegwolf. 2007. Human impacts on tree-ring growth reconstructed from stable isotopes. In Dawson TE, RTW Siegwolf eds. Stable Isotopes as Indicators of Ecological Change. Elsevier. p 45-57.

Schleser GH, J Frielingsdorf , A Blair. 1999. Carbon isotope behaviour in wood and cellulose during artificial aging. Chemical Geology 158: 121-130.

Schweingruber F. 1996. Tree rings and environment: Dendroecology. Berne, Switzerland. Paul Haupt Verlag. 609 p.

Silva LCR, WR Horwath. 2013. Explaining Global Increases in Water Use Efficiency: Why Have We Overestimated Responses to Rising Atmospheric $\mathrm{CO}_{2}$ in Natural Forest Ecosystems? PLOS ONE 8(1): e53089. doi:10.1371/journal.pone.0053089.

Sternberg L, J De Niro. 1983. Isotopic composition of cellulose from C3, C4 and CAM plants growing near one another. Science 220: 947-949.

Tans P, A De Jong A, W Mook. 1978. Chemical pre-treatment and radial 484 flow of ${ }^{14} \mathrm{C}$ in tree rings. Nature 271: 234-235.

Voltas J, JJ Camarero, D Carulla, M Aguilera, A Ortiz, J P Ferrio. 2013. A retrospective, dual-isotope approach reveals individual predispositions to winter-drought induced tree dieback in the southernmost distribution limit of Scots pine. Plant, Cell and Environment 36: 1435-1448.

Warren C, J McGrath, M Adams. 2001. Water availability and carbon isotope discrimination in conifers. Oecologia 127: 476-486. 